\title{
Considerações sobre a Querela Nullitatis e a questão da existência, validade e eficácia dos atos judiciais
}

\author{
Considerations on Querela Nullitatis and the question of the existence, validity and \\ effectiveness of judicial acts
}

Clarissa Vencato da Silva'

'Faculdade Cathedral, Brasil

\section{Resumo}

\begin{abstract}
Este trabalho aborda um tema de extrema relevância prática, principalmente pela necessidade de compreender as diferentes espécies de vícios dos atos judiciais e a consequência jurídica de cada um quando reconhecida a inexistência, a invalidade e a ineficácia, sobretudo quando, de tão grave, o vício torna-se passível de nulidade. Assim, a importância do estudo das diferenças das imperfeições dos atos processuais é imprescindível para compreender o instituto da querela nullitatis e as hipóteses de cabimento, bem como as diferenças em relação à ação rescisória.
\end{abstract}

Palavras-chave: Prova; Sentença; Nulidade; Inexistência; Invalidade; Ineficácia; Querela nullitatis.

\begin{abstract}
This study approaches a theme of extreme practical relevance, mainly due to the need of understanding the different types of imperfections in judicial acts and the legal consequence of each when the inexistence, invalidity and ineffectiveness of judicial acts are recognized, especially when it is so relevant, the imperfection becomes liable to nullity. Thus, the importance of studying the differences of the imperfections of procedural acts is essential to understand the institute of the querela nullitatis and the hypotheses of fit, as well as the differences in relation to the rescissory action.
\end{abstract}

Keywords: Judicial sentence; Nullity; Inexistence; Invalidity; Ineffectiveness; Querela nullitatis.

\section{Introdução}

A questão da invalidade de atos judiciais gera tormentosas dúvidas de ordem prática, em especial quando se pretende identificar a irregularidade do ato e classificá-la juridicamente da forma correta para identificar o meio de impugnação adequado para obter o seu desfazimento.

A importância da conceituação e diferenciação entre a existência, validade e eficácia do ato processual, bem como o estudo das nulidades e os meios de impugnação das decisões judiciais maculadas por vícios decorre não apenas da necessidade de compreender estes fenômenos processuais e seus efeitos práticos, como também permitir a identificação do meio de impugnação adequado para o desfazimento da irregularidade ou cessação dos efeitos do ato jurídico que padece de imperfeição que o torna inexistente, inválido ou ineficaz, ou mesmo nulo. 
Assim, no que se refere aos atos judiciais fulminados por irregularidade, incompletude, ou outra imperfeição, a técnica jurídica adequada para a invalidação e desfazimento do ato depende essencialmente da perfeita identificação da irregularidade contida no comando judicial.

Justamente por isso, boa parte dos atos processuais possuem previsão legal estabelecendo a forma de praticá-los, cuja inobservância, quando não é passível de convalidação, poderá culminar na inexistência, invalidação, ineficácia ou mesmo na nulidade do ato, que, por ser defeituoso e gravemente viciado, pode comprometer o resultado tipicamente previsto em lei.

\section{A questão da existência, validade e eficácia dos atos judiciais}

A análise de um fato/conduta humana, por si só, nada representa no mundo jurídico, a menos que seja compreendida sob o teor de uma norma jurídica, tornando-se, então, fato jurídico, o que normalmente ocorre quando do conflito de interesses entre sujeitos de direito, os quais invocam a incidência da norma jurídica para dirimir ou prevenir o conflito. Ou seja, a conduta deve caracterizar um tipo/fattispecie com aptidão para produzir consequência jurídica previamente prevista em lei (PASSOS, 1989).

Dessa forma, segundo ensina Calmon, a existência ou inexistência de um fato jurídico tanto pode decorrer da ausência do suposto (conduta humana) exigida para a produção da consequência jurídica, como também pode ocorrer mediante a efetiva existência material de determinada conduta humana, mas que não se coaduna com o suposto exigido pela norma jurídica.

Assim, a forma, sujeito e objeto são elementos essenciais de toda relação jurídica, de modo que existem pressupostos objetivos e subjetivos para que um ato jurídico possa assim ser considerado, exista, seja válido e eficaz. Dessa forma, deve haver adequação (atendimento aos pressupostos) entre o ato material e a exigência legal, devendo haver, ainda, correspondência entre o ato material praticado com a estrutura do ato material previsto normativamente, para, então, tornar-se ato jurídico existente, válido e eficaz (PASSOS, 1989).

Por questões de ordem lógica, o plano da existência é o primeiro a ser analisado. Fazendo-se uma comparação com a lógica da Escada Ponteana idealizada por Pontes de Miranda, o plano da existência é o degrau-base que permite que os demais degraus existam e possam se sustentar.

Segundo Daniel Assumpção Neves (2013), se um ato jurídico for considerado inexistente juridicamente, não passará de mero fato, porquanto ausentes os pressupostos de existência, de modo que não haverá que se falar em validade, não podendo ser válido um ato jurídico que sequer existe). Entende ser o mais grave dos vícios, porquanto trata-se de ato carente de elementos constitutivos mínimos.

Assim, não se confunde a existência jurídica com a existência fática. A inexistência do ato processual é vício absolutamente insanável, que não se convalida jamais e que também pode, a qualquer tempo e independente de prazo, ser suscitado por meio de ação declaratória de inexistência de ato jurídico (que, nada mais é do que um dos vários nomes atribuídos à querela nullitatis).

Eis aqui uma primordial diferença entre a inexistência e a nulidade absoluta, pois, ao passo que a nulidade absoluta convalida-se após o prazo de dois anos sem que tenha sido interposta a respectiva ação rescisória e dá lugar à chamada coisa julgada soberana, a alegação de inexistência não está sujeita a qualquer prazo:

(...) a decisão proferida em processo que seja juridicamente inexistente, ou conte com ato juridicamente inexistente, que a contamina, não se convalida, podendo o vício ser alegado a qualquer momento. Embora inexistente, é apto a gerar efeitos até que venha decisão judicial declarando-o como tal, da mesma forma que ocorre com as nulidades relativas e absolutas, distinguindo-se destas somente pela impossibilidade de convalidação. Uma sentença sem a assinatura do juiz ou assinada por alguém não investido na jurisdição, embora exista no plano fático, não passa de mero pedaço de papel sem importância jurídica (NEVES, 2013, p. 292). 
Assim, o Código de Processo Civil exige o preenchimento de série de pressupostos processuais quanto à pessoa do juiz: competência absoluta, investidura jurisdicional, capacidade subjetiva (ausência de suspeição), para que esteja legalmente autorizado a dizer o direito. Bem assim, exige-se das partes, além do interesse e legitimidade para postular em juízo, o atendimento a pressupostos processuais objetivos e subjetivos, tais como: petição inicial apta, tríplice capacidade (capacidade de ser parte, capacidade processual e capacidade postulatória), citação, onde o preenchimento destes pressupostos caracteriza a adequação entre o ato material e a exigência legal, porém, ainda não tem aptidão para fazer com que a sentença seja válida e eficaz (produza efeitos no mundo jurídico) enquanto pendente de publicação. Somente após publicada há adequação plena.

Voltando ao raciocínio inicial acerca do sujeito, objeto e forma, verifica-se que a sentença não é ato que pode ser praticado por todo e qualquer sujeito de direitos, mas tão-somente por sujeito dotado de investidura constitucional para prestar jurisdição, de modo que sentença proferida por chefe de secretaria ou por oficial de justiça é inexistente (pois nem sentença chega a ser), inexistência jurídica essa que decorre diretamente da inexistência do sujeito apto a sentenciar. Sendo inexistente, não será, consequentemente, válida ou eficaz (PASSOS, 1989).

Some-se aos exemplos de inexistência do ato processual anteriores a hipótese de sentença proferida por chefe de secretaria, apresentação de petição inicial ou contestação assinadas por estagiário de direito ou por advogado sem procuração nos autos, de modo que os atos por estes praticados são inexistentes.

No entanto, NEVES (2013) esclarece que, muito embora alguns atos judiciais juridicamente inexistentes, por sua própria existência fática, são capazes de gerar efeitos até que sua inexistência seja reconhecida por sentença (como no caso da sentença proferida por juiz aposentado devidamente executada e cumprida pelo devedor, produzindo efeitos fáticos mesmo sendo inexistente), há muitos outros atos jurídicos que, justamente por serem inexistentes juridicamente, são inaptos a produzir qualquer efeito jurídico por não possuírem eficácia, porquanto padecem de incompletude tão significativa que surge uma barreira jurídica intransponível que impede a produção de efeitos, ineficácia essa que independe de declaração judicial, a exemplo da sentença sem a parte dispositiva, de modo que seria plenamente impossível qualquer eficácia por parte do referido ato judicial inexistente.

Assim, uma decisão judicial considerada existente juridicamente pode ser impugnada por dois meios de impugnação, quais sejam, o recurso e a ação rescisória. Porém, no direito brasileiro, há duas hipóteses em que uma sentença existente pode ser impugnada mesmo após vencido o prazo da ação rescisória: no caso em que fora proferida sentença em processo com réu que não teve conhecimento do processo, seja pela ausência de citação, seja por vício na realização da mesma que invalida o ato e viola o devido processo legal. Tais defeitos tornam-se vícios transrescisórios, impassíveis de convalidação pelo decurso do tempo e de se tornarem coisa julgada.

Dessa forma, uma sentença judicial pode ser considerada inexistente tanto em razão de ter sido proferida no âmbito de um processo inexistente por ausência de pressupostos processuais, quanto no caso em que, mesmo que proferida dentro de uma relação jurídico-processual existente e válida, lhe faltariam elementos essenciais para que seja um ato processual existente, vícios esses que, dada a sua extrema gravidade, podem ser alegados a qualquer tempo e não se convalidam pelo decurso do mesmo, tampouco possuem aptidão para transitar em julgado.

Fernando Gajardoni, citando Teresa Arruda Alvim (Nulidade do Processo e da Sentença, $4^{\mathrm{a}}$ Ed, 1998), traz um rol exemplificativo do que seriam sentenças inexistentes: sentença sem decisório, sentença onde houve citação nula aliada à revelia, sentença não escrita ou sem assinatura do juiz, sentenças proferidas em processos onde haja carência da ação, dentre outros.

Dessa forma, uma vez diante da figura da inexistência jurídica do ato judicial, está-se diante também de sua invalidade e ineficácia em razão da inadequação, não se tratando de nulidade, porquanto com esta não se confunde jamais, uma vez que, se o ato inexiste, nem mesmo nulo poderá ser.

No tocante ao aspecto da validade dos atos judiciais, para fins de melhor compreensão do presente trabalho, este aspecto será novamente explorado no tópico seguinte relativo às nulidades, as 
quais maculam o ato processual no aspecto da validade, nunca da existência, até porque somente pode ser nulo um ato processual que existe juridicamente.

Isto quer dizer que, antes de qualquer coisa, o ato processual precisa existir para que possa vir a ser válido e eficaz, ou mesmo para que possa ser inválido. Portanto, se uma relação jurídico-processual vem a ser inexistente, assim também será o pronunciamento jurisdicional, o que não poderia jamais ser objeto de ação rescisória para a sua declaração, porquanto um ato inexistente, por razões óbvias, jamais poderia ser válido ou eficaz.

Dessa forma, Calmon de Passos (1989) explica que uma sentença proferida por um não-juiz, por exemplo, seria caso de sentença inexistente, porquanto ausente a investidura constitucional para prestar jurisdição, podendo tal inexistência ser arguida por meio de querela nullitatis a qualquer tempo. Já uma sentença sem fundamento ou relatório, ainda que preenchidos os demais pressupostos processuais, será uma sentença existente, porém, inválida. Assim, conforme será abordado mais adiante, a ação rescisória tem por objeto uma sentença existente e válida e transitada em julgado, porém, maculada por um vício considerado grave e inadmissível, evidenciando uma nulidade.

Assim, DIDIER JR e CUNHA (2017) explicam que a ação rescisória permite o desfazimento de defeitos ligados à validade (nas hipóteses art. 966, II e IV, CPC) e à justiça (nas hipóteses do art. 966, VI e VII, CPC) do ato judicial, não sendo correto traçar uma ligação direta e indistinta entre a ação rescisória e a invalidação da sentença, até porque a querela nullitatis presta-se exclusivamente à invalidação da sentença, nesses casos previstos.

No que tange ao plano da eficácia, no entender de Daniel Assumpção Neves (2013), importante fazer a distinção da questão da existência, validade e eficácia entre o âmbito do direito processual e do âmbito do direito material civil, por entender o autor ser perfeitamente possível a um ato inexistente produzir efeitos como se válido e eficaz fosse, onde a cessação de seus efeitos somente poderia ocorrer judicialmente, por meio de decisão judicial reconhecendo o vício, conforme trecho a seguir:

\footnotetext{
"Imagine-se uma sentença proferida por um juiz aposentado, em nítido caso de inexistência do ato processual (faltou o pressuposto processual subjetivo da investidura). A parte vencedora poderá executar tal sentença, e caso o executado nada alegue é possível imaginar tal execução chegando ao seu final com a satisfação do direito do exequente. Enquanto não existir a decisão que declare o ato inexistente, portanto, é correto afirmar-se que mesmo o ato inexistente gera efeitos. (...) É importante consignar que qualquer que seja o vício do ato processual, o mesmo somente não será apto, ou deixará de produzir efeitos, após decisão judicial que reconheça tal imperfeição do ato. Significa dizer que no direito processual não existe a figura do ato jurídico nulo de pleno direito, que desde o momento de sua prática não gera efeitos, sendo todos os atos meramente anuláveis, já que sempre dependem de decisão judicial a reconhecer o vício, somente deixando de produzir efeitos após a prolação da decisão. É possível, em razão de tal regra, inclusive imaginar situação em que ato viciado (insista-se, qualquer espécie de imperfeição) gere efeitos eternamente, como se válido fosse, bastando para tanto não existir decisão judicial que ateste o vício, declarando-o nulo ou até mesmo juridicamente inexistente” (NEVES, 2013, p. 283/284)
}

Nesse sentido, Calmon (1989) esclarece que há distinção entre validade e eficácia do ato, pois um ato pode ser considerado válido se for considerado típico (que preenche as exigências legais), porém, será ineficaz se pendente um ato posterior que não integra a estrutura do tipo, mas que é responsável por sua eficácia, tal como no caso da sentença, que depende de publicação para que possa surtir seus efeitos jurídicos. A publicação não integra a estrutura do tipo do ato judicial decisório, mas é essencial para que se torne eficaz.

Dessa forma, há atos jurídicos mais complexos que, para obterem eficácia, é necessária a prática ou ocorrência de um ato posterior que nada tem a ver com a estrutura do ato, a exemplo das sentenças judiciais, que, além de exigir o preenchimento de pressupostos objetivos e subjetivos quanto ao juiz e as partes e uma estrutura de relatório, fundamento e parte dispositiva, sua produção de efeitos depende obrigatoriamente de um ato posterior, qual seja, a publicação (PASSOS, 1989). 


\section{A questão das Nulidades absolutas e relativas dos atos processuais}

Conforme já abordado anteriormente, frequentemente muitos operadores do Direito referem-se automaticamente a atos processuais imperfeitos como atos nulos. No entanto, não se pode generalizar e tratar toda e qualquer irregularidade do ato como nulidade, porquanto há outras espécies de invalidade que não se confundem, nem mesmo minimamente, com nulidades, sendo meros atos irregulares, cuja imperfeição não é relevante juridicamente o suficiente para fulminar o ato de nulidade ou ensejar rompimento da coisa julgada.

Assim, THAMAY e TESHEINER (2016) classificam as imperfeições dos atos processuais em três categorias: os vícios preclusivos, de pouca gravidade, que não acarretam nulidade, mas sim preclusão; vícios rescisórios, cuja presença na sentença enseja a rescisão da res judicata por meio de ação rescisória; e vícios transrescisórios, consistentes na ausência de requisitos que ensejam a declaração de ineficácia, nulidade ou inexistência da sentença, ainda que já ultrapassado o prazo da ação rescisória.

No campo das nulidades, Calmon de Passos (1989) ensina que a nulidade se trata, na verdade, de uma desqualificação de uma situação jurídica em razão de sua atipicidade, considerando-a inapta para produzir consequências jurídicas que lhe seriam inerentes, modo que somente é relevante a ser considerada nulidade a atipicidade que impacta diretamente na consequência normativamente prevista.

Assim, Calmon de Passos (1989) traça três premissas básicas que norteiam a Teoria das Nulidades e sua identificação: a análise quanto aos ato-fatos jurídicos; a análise quanto aos ato jurídicos em sentido estrito; e a análise quanto aos ato-fatos jurídicos em sentido amplo.

No que tange aos ato-fatos jurídicos, não há que se falar em nulidade, diante da irrelevância do sujeito-agente, cuidando-se apenas da existência ou não do suposto legal (PASSOS, 1989).

Quanto aos ato-fatos jurídicos em sentido estrito, a consequência jurídica é imputada ao suposto em razão exclusivamente do que é prescrito em lei, não havendo necessidade de adequação entre a vontade do sujeito ao resultado, onde a consequência prevista em lei é excluída do âmbito da vontade do sujeito. Assim, a eventual atipicidade seria irrelevante quanto atingida a consequência prescrita em lei, sendo mera irregularidade insuficiente para gerar nulidade, porquanto o suposto se desqualifica a partir da consequência jurídica e é assim que se verifica eventual invalidade, não a partir da conduta do agente, imperando a fungibilidade das formas, onde a inadequação do suposto não gera a inadequação da consequência quando esta é atingida, privilegiando-se a vontade da lei (PASSOS, 1989).

No que se refere aos atos-fatos em sentido amplo, a verificação de invalidade reside basicamente na análise da autonomia da vontade dos agentes, que ganha vital relevância e interfere diretamente nas consequências jurídicas, a invalidade se verifica quando há vício na vontade dos agentes, de modo que a prevalência do resultado deixa de ser uma questão de exegese da norma de direito objetivo para ser uma questão de exegese da norma posta pela vontade privada. Assim, eventual convalidação da nulidade somente poderia ocorrer por vontade dos próprios agentes envolvidos no negócio jurídico, superando a atipicidade e concretizando a tipicidade do suposto (CALMON DE PASSOS, 1989).

Ainda, no que tange à diferenciação entre nulidade absoluta e relativa no âmbito do direito público e no campo dos atos jurídicos em sentido estrito, a obra de Calmon (1989) torna-se ainda mais importante por ter servido de base para a sistematização atual das Nulidades no CPC/15, que recebe tratamento diverso daquele previsto no CPC/39 e CPC/73, porquanto considera tal diferenciação irrelevante, sob o argumento de que o ato é ou não é fulminado de atipicidade juridicamente relevante, onde o reconhecimento dessa atipicidade operará ex tunc ou ex nunc, não havendo que se falar em nulidade absoluta (ex tunc) e relativa (ex nunc), sempre buscando preservar o alcance da consequência jurídica imposta pela norma.

Assim, Calmon propõe que não seja supervalorizada a diferença entre nulidade absoluta e relativa, tampouco vê importância prática na necessidade de previsão das chamadas nulidades cominadas ou não cominadas, mas sim que seja sempre considerada, quando possível, a possibilidade de aproveitamento do ato e os fins do processo, sobretudo quando a imperfeição do ato não trouxer prejuízo às partes e ao 
feito. A esse respeito, a redação do art. 277 do CPC/2015 foi feliz ao eliminar a questão da cominação da nulidade, de modo que sua verificação depende exclusivamente da avaliação do grau de prejuízo no caso concreto.

O sistema do Código de Processo Civil de 1939 supervalorizava a questão das nulidades cominadas e não cominadas, conforme se verifica dos artigos 273 e 274, daquele Código. E, muito embora juristas como Calmon de Passos já houvessem teorizado, durante a vigência do Código de 1939, acerca da pouca utilidade prática desse tipo de classificação, o Código de 1973, em seus artigos 243 e 244 , repetiu esse apego legislativo às nulidades cominadas e não cominadas, como se um ato pudesse ou não ser automaticamente considerado nulo só pela existência de cominação legal sem que seja sopesada a consequência concreta da imperfeição do ato para avaliar a gravidade do vício.

Nesse sentido, uma grande contribuição deixada por Calmon, sem dúvidas, foi propor uma Teoria das Nulidades que não supervalorizava uma diferenciação legal entre nulidades cominadas e não cominadas, por entender - e com muita razão - que a nulidade deve ser avaliada pelo magistrado quanto ao seu grau de prejuízo e quanto às consequências que esta atipicidade do ato gera para o processo e para as partes, sendo, destarte, um estado do ato processual que deve ser verificado no caso concreto, e não algo que será nulo absolutamente ou relativamente só porque está indistintamente previsto na lei.

A antiga sistematização das chamadas nulidades cominadas e não cominadas do CPC/39 e CPC/73 possuíam pouca importância prática, porquanto amarravam o sistema em detrimento da valorização do atingimento da finalidade do ato que, muitas vezes embora imperfeito, não trouxe prejuízo às partes. Além disso, essa antiga classificação tentava o impossível - exaurir um rol de nulidades que podem ocorrer no curso do processo sem preocupação com a ocorrência ou não de prejuízo às partes e ao atingimento da finalidade.

Impende esclarecer que a lei não é um fim em si mesma, de modo que, ainda que defeituosos por terem sido praticados em desconformidade com o formato legal previsto, se atingirem o objetivo de produzir os efeitos pretendidos, tais imperfeições do ato processual não gerarão nulidade, em homenagem ao Princípio da Instrumentalidade das formas consubstanciado no art. 188, do Código de Processo Civil, uma vez que, ao passo que a ausência de forma para a prática dos atos poderia ocasionar desordem processual, a lei não é um fim em si mesma a ponto de, ao mínimo sinal de imperfeição na prática do ato, fulminá-lo automaticamente com alguma nulidade.

Para NEVES (2013), a instrumentalidade das formas caracteriza uma forma de exceção à regra da invalidação de atos defeituosos, de modo que tal princípio reconhece o caráter defeituoso/imperfeito do ato, mas não lhe inflige automaticamente os efeitos da nulidade para não prestigiar o formalismo exagerado, permitindo que os efeitos previstos em lei sejam alcançados, desde que não haja prejuízo a nenhuma das partes quanto às suas garantias constitucionais.

Dessa forma, existem atos defeituosos que não geram nulidade, assim como existem atos processuais que, justamente por serem defeituosos, podem gerar nulidade, ou diferentes formas de nulidade. Daí a importância fundamental de distinguir ato viciado de nulidade, porquanto é a gravidade da imperfeição do ato que guiará o tratamento procedimental dessa nulidade, quem poderá alegá-la, prazos e formas de alegação, etc (NEVES, 2013).

Um ato viciado, dito imperfeito, é aquele praticado em desconformidade ao padrão legal exigido. A formalidade na prática de atos processuais, apesar de não ser um fim em si mesma, visa conferir segurança jurídica às partes do processo, uma vez que, sempre que pratica um ato em conformidade com a exigência legal para a sua prática, atinge-se o objetivo de obter os efeitos normais daquele ato.

Daniel neves (2013) ensina que, da mesma forma que a lei, ao estabelecer forma para a prática de determinados atos processuais, garante a obtenção dos resultados previstos legalmente, também estabelece sanções processuais para a hipótese da prática dos atos processuais em desconformidade com o padrão legal estabelecido, de modo que a imperfeição do ato trará como consequência à parte que o praticou de forma irregular a chamada nulidade, que impede a produção de efeitos previstos em lei e consequentemente o alcance do resultado pretendido. 
Daniel Neves (2013) entende a nulidade relativa como um instituto de importância política imensa, que visa garantir a previsibilidade dos efeitos do atos processuais praticados pelas partes e a proteção aos interesses destas, porquanto a forma prevista em lei para praticá-los visa, acima de tudo, garantir o devido processo legal.

Dessa forma, a nulidade relativa tem como uma de suas características a necessidade de ser alegada pela parte em favor de quem aproveita a decretação de nulidade do ato, no prazo e forma estabelecidos em lei, sob pena de preclusão e posterior convalidação do ato, não podendo ser reconhecida de ofício pelo julgador (NEVES, 2013).

E, no tocante à legitimidade para a arguição da nulidade relativa, Neves (2013) esclarece que somente a parte inocente, isto é, que não deu causa à nulidade relativa é legitimada para suscitá-la, nos termos dos artigos 276 a 283, do Código de Processo Civil. E, quanto ao prazo, cabe à parte alegar o vício do ato na primeira oportunidade em que lhe couber falar nos autos, sob pena de preclusão e convalidação do ato em razão do silêncio.

Importante destacar que o artigo 282, §2º , do Código, estabelece que, sempre que for possível ao juiz julgar o mérito em favor da parte a quem aproveita a alegação de nulidade, este não se pronunciará quanto à decretação de nulidade ou dever de refazimento do ato imperfeito.

A nulidade absoluta, por seu turno, reside na mácula insanável que fulmina o ato processual imperfeito, de modo que sua invalidade atinge não apenas os interesse das partes, mas o sistema de justiça como um todo, por violar matérias de ordem pública, que transcendem aos interesses dos sujeitos do processo, de modo que pode ser alegada a qualquer tempo e grau de jurisdição pelas partes - inclusive pela parte que deu causa, a exemplo do autor quando alega incompetência absoluta do juízo - , bem como de ofício pelo julgador, não sendo passível de ser atingida pela preclusão (NEVES, 2013).

Dessa forma, para aqueles que concordam com a dicotomia das nulidades em absolutas e relativas, é possível verificar a profunda diferença entre ambas, porquanto a nulidade dita absoluta pode ser arguida inclusive após o fim do processo e da formação da coisa julgada, por meio de ação rescisória, porque torna-se vício de rescindibilidade, uma vez que o trânsito em julgado é medida sanatória geral das nulidades absolutas. (NEVES, 2013).

\section{Atos meramente irregulares e a inadmissibilidade}

Os chamados atos meramente irregulares caracterizam imperfeições de pouca relevância, que em nada afetam a estrutura ou mesmo a produção dos efeitos do ato processual, até porque não possuem o condão de gerar qualquer prejuízo às partes ou mesmo à relação jurídico-processual. Destarte, não implica a inexistência do ato, tampouco sua invalidade ou ineficácia, tampouco ocasiona nulidade absoluta ou relativa.

Assim, NEVES (2013) preleciona que tais irregularidades de menor relevância são uma forma autônoma de vício dos atos processuais, porquanto ocasionam, no máximo, eventual responsabilidade civil das partes, bem como punições disciplinares a juízes, serventuários, partes ou advogados, citando como exemplo as petições em fontes coloridas ou de cores chamativas, rasuras ou uso de língua estrangeira.

E, no tocanteà chamada inadmissibilidade, sobre a qual não haverá, neste estudo, aprofundamento teórico, trata-se de uma forma de invalidação que não se confunde com a nulidade, porquanto possui um fundamento teórico totalmente diferente da nulidade.

Assim, a inadmissibilidade, segundo Calmon (1989), mesmo sendo espécie de invalidade e ineficácia, não se confunde com a inexistência ou mesmo com a nulidade. A inadmissibilidade está ligada à falta de pressupostos atinentes aos atos do procedimento, o que afeta não apenas atos isolados do procedimento, mas o procedimento como um todo, o que acarretaria a falta de aptidão do procedimento para atingir seus resultados típicos e permitir o exame do mérito. É, destarte, uma espécie de invalidade e de ineficácia que não se confunde com a inexistência ou a nulidade. 


\section{Breve panorama acerca da ação rescisória}

Antes de discorrer sobre a querela nullitatis e suas características, é fundamental traçar um breve estudo sobre a ação rescisória, sua natureza, cabimento e objeto de abrangência, a fim de facilitar a diferenciação entre ambos os institutos.

Trata-se a ação rescisória de ação de natureza constitutiva negativa, que visa atacar sentenças e decisões de mérito já transitadas em julgado, portanto, abarcadas pela coisa julgada material, visando rescindi-la e permitir a prolação de uma nova decisão, como forma de garantir segurança jurídica às partes. Verdadeiro meio de impugnação às decisões judiciais, porém, de decisões transitadas em julgado (LEMOS, 2016).

Assim, LEMOS (2016) ensina que, ao mesmo tempo em que visa resguardar o interesse público e a segurança jurídica, garantindo que um vício de extrema gravidade, ainda que tenha se tornado imutável, possa ser desconstituído por meio da relativização da autoridade da coisa julgada, há um prazo para que tal providência seja adotada pelas partes, que é de dois anos.

Passado o referido prazo legal, o vício, ainda que grave, torna-se imutável de forma permanente e absoluta, não mais sendo possível rescindir a coisa julgada material por meio da ação rescisória.

Importante destacar que, muito embora seja meio de impugnação de decisões judiciais de mérito transitadas em julgado, não figura no rol de espécies recursais do art. 994 do CPC, justamente em razão de sua natureza jurídica de ação autônoma de impugnação, que demandará análise cognitiva pelo julgador, respeito ao contraditório, possivelmente demandará fase probatória, e é proposta em competência diversa daquela onde fora proferida a decisão de mérito rescidenda, porquanto é de competência originária dos Tribunais aos quais o juízo prolator da decisão que se pretende rescindir esteja subordinado (LEMOS, 2016).

Importante destacar, também, que o rol das hipóteses de cabimento da ação rescisória constantes no art. 966 do CPC é taxativo, de modo que, em se tratando de vício da decisão de mérito transitada em julgado que não figure no rol em comento de hipóteses de relativização da coisa julgada, não será possível atacá-lo por meio de ação rescisória, mas sim por via diversa, a exemplo da ação anulatória contra ato judicial (ex: contra decisões judiciais homologatórias) e a própria querela nullitatis, objeto principal do presente estudo.

A ação rescisória tem por objeto decisões judiciais (decisões interlocutórias que resolvem mérito, sentenças, acórdãos etc) transitadas em julgado e imutabilizadas pela coisa julgada material. Tais decisões podem até ser fulminadas de nulidade, porém, são sempre existentes juridicamente, ainda que viciadas, defeituosas. Eis aqui o ponto fulcral que diferencia o cabimento da ação rescisória do cabimento da querela nullitatis, pois a nulidade está sempre relacionada à validade dos atos judiciais, não à existência dos mesmos.

A primeira hipótese de cabimento da ação rescisória (art. 966, I, CPC) refere-se a situações em que a sentença tenha sido motivada por ato de prevaricação, corrupção ou concussão do juiz, onde o eventual crime praticado pelo magistrado nos autos enseja o rompimento da coisa julgada material. "Se o juiz comete algum outro crime no processo, não cabe ação rescisória (...). Não há uma análise sobre a sentença e seu conteúdo, somente se houve o crime relativo ao processo" ((LEMOS, 2016, p. 578).

A segunda hipótese de cabimento (art. 966, II, CPC) refere-se a sentença proferida por juiz impedido ou por juízo absolutamente incompetente. Note-se que o rol das hipóteses de impedimento do art. 144 do CPC é taxativo, de modo que estará configurado sempre que incorrer em alguma dessas hipóteses, não se tratando, na espécie, de suspeição prevista no art. 145 do CPC, mas tão-somente do impedimento. Ademais, a segunda parte deste inciso refere-se à ausência de pressuposto processual denominado competência absoluta, estampado no artigo 5ํㅜ, LIII, da Constituição Federal e no art. 62 , do CPC, e que é matéria de ordem pública, conforme disposição do art. 337, II e 64, §2º, do CPC.

A terceira hipótese de cabimento da ação rescisória (art. 966, III, CPC) consiste na eventual prática de dolo ou coação pela parte vencedora em detrimento da parte vencida, ou em caso de colusão 
ou simulação entre as partes para cometer fraude à lei, o que, além de violar os deveres objetivos de boa-fé e lealdade processual, também enseja, no caso da segunda parte do inciso, o direito a eventuais terceiros prejudicados (ex: credores e o próprio Ministério Público) a moverem a ação rescisória em razão do conluio perpetrado.

A quarta hipótese de cabimento da ação rescisória (art. 966, IV, CPC) reside na ofensa à coisa julgada, o que ocorre quando já proposta uma demanda, sobre a qual é proferida sentença de mérito pacificando a controvérsia, onde, após o trânsito em julgado desta decisão, vem a ser proposta nova demanda idêntica, sendo proferida nova sentença de mérito, fazendo surgir evidente conflito de coisas julgadas sobre mesma questão fático-jurídica. Nesse caso, deve prevalecer a primeira sentença, devendo ser proposta a ação rescisória para rescindir a imutabilidade que recaiu sobre a segunda sentença, invalidando-a.

A quinta hipótese de propositura da ação rescisória (art. 966, V, CPC), consubstancia-se quando houver manifesta violação não apenas à literal disposição de lei (tal qual no regime do CPC/73), mas também, conforme parágrafos $5^{\mathbf{o}}$ e $6^{\circ}$, quando houver violação a norma criada por meio do microssistema de precedentes obrigatórios do artigo 927, como no caso de eventual aplicação equivocada do precedente em hipótese fática à qual não se aplique a tese jurídica firmada no precedente, sendo ônus da parte que ajuíza a ação rescisória demonstrar, na petição inicial endereçada ao Tribunal, o distinghishng demonstrando o erro na utilização do precedente na decisão rescidenda ${ }^{1}$.

A sexta hipótese de cabimento da ação rescisória (art. 966, VI, CPC) refere-se aos casos em que a decisão de mérito transitada em julgado fundou-se em prova falsa, falsidade essa ou apurada em procedimento criminal, ou cuja demonstração irá ocorrer na própria ação rescisória.

A sétima hipótese de cabimento da ação rescisória (art. 966, VII, CPC) ocorre quando surgir prova nova que possa influir substancialmente no resultado da decisão, cuja existência não se tinha conhecimento, ou cuja apresentação nos autos não foi possível no momento processual adequado. $\mathrm{O}$ CPC $/ 73^{2}$ somente previa tal hipótese no caso de documento novo, ao passo que a atual redação estende o cabimento em se tratando de qualquer meio de prova em direito admitido.

A oitava hipótese de cabimento da ação rescisória (art. 966, VIII, e $\$ 1^{\circ}$, CPC) diz respeito à ocorrência de erro de fato, consistente na declaração de inexistência, por parte do juiz, de fato efetivamente ocorrido, ou na declaração de existência de fato que não ocorreu, ocasionando uma equivocada aplicação do direito, em desconformidade com a realidade fática trazida nos autos.

Há, ainda, uma hipótese escondida no texto do CPC, que é a possibilidade - ainda que não figure no rol do art. 966 - de ajuizamento de ação rescisória na hipótese de coisa julgada inconstitucional, a qual possui previsão legal no art. 525, \$15, do Código. Trata-se da situação em que a matéria sobre a qual fora proferida decisão transitada em julgado é posteriormente declarada inconstitucional em sede de controle de constitucionalidade concreto ou abstrato, cujo prazo de dois anos para ajuizamento será contado da decisão proferida pelo Supremo Tribunal Federal, sem qualquer limite temporal contado do trânsito em julgado da decisão-objeto da ação rescisória (LEMOS, 2016).

Alguns autores, como PORTO e USTARRÓZ (2009) entendem que o rol de cabimento da ação rescisória deveria ser exemplificativo, porquanto a relativização da coisa julgada, muitas vezes, é importante para que se efetivem outras garantias constitucionais - muito embora a própria coisa julgada seja uma garantia constitucional -, de forma a permitir a amplitude das hipóteses de desfazimento de erros na aplicação do direito. Defendem, ainda, que o prazo de dois anos deveria ser contado não a partir do trânsito em julgado, mas sim a partir do conhecimento do vício que macula o decisum.

\footnotetext{
1 Vinicius Lemos (2016) também cita como exemplo de cabimento na forma do art. 966, V, $\$ 5^{\circ}$ e $6^{\circ}$, uma situação em que o juízo a quo deixe de aplicar um precedente obrigatório sem que tenha havido a devida aplicação de uma das técnicas de superação do mesmo, tais como o signaling, distinguishing, overruling, dentre outros.

2 Art. 485, VII, CPC/73.
} 


\section{Querela Nullitatis: conceito e objeto de incidência}

Também conhecida por ação declaratória de inexistência, ação declaratória de nulidade insanável e ação de nulidade de sentença, a querela nullitatis insanabilis, inobstante a ausência de previsão legal acerca de sua existência ${ }^{3}$, é um instituto interessantíssimo e de inegável importância para o desfazimento de invalidades de atos judiciais que não sejam objeto de ação rescisória, a qual, conforme já abordado anteriormente, somente tem cabimento nas hipóteses do art. 966 do CPC, e que deve ser interposta impreterivelmente no prazo decadencial de 02 anos.

A primeira diferença existente entre a querela nullitatis e a ação rescisória é a competência para a sua propositura. Ao passo que a rescisória é de competência originária do Tribunal ao qual o juízo prolator da sentença rescidenda está vinculado, a querela nullitatis deve ser proposta perante o mesmo juízo prolator da sentença inexistente ou nula, seja ele um juízo de primeiro grau ${ }^{4}$, podendo também ser proposta perante um Tribunal, caso a decisão objeto da querela tenha sido proferida em ação de sua competência originária, ou caso a sentença de piso tenha sido substituída por um acórdão do respectivo tribunal $^{5}$ (CUNHA, 2019).

Dessa forma, a ação rescisória tem por objeto decisões judiciais juridicamente existentes, onde as decisões judiciais inexistentes juridicamente (ainda que existam no plano fático) serão objeto de ação declaratória de inexistência.

A esse respeito, CUNHA e DIDIER JR (2017) citam um exemplo de cabimento de querela nullitatis contra sentença existente, no caso do réu cujo processo tramitou à tua total revelia, nunca tendo sido citado nos autos. Transcorrido o prazo de dois anos de propositura da rescisória, cabível é, a qualquer momento, a querela nullitatis, diante da existência de vício transrescisório:

\footnotetext{
"Em regra, a nulidade absoluta que se transformou em vício de rescindibilidade após o trânsito em julgado atinge a estabilidade definitiva com o decurso do prazo de dois anos da ação rescisória, em fenômeno conhecido como “coisa julgada soberana”. Ocorre, entretanto, que existem nulidades absolutas tão graves, tão ofensivas ao sistema jurídico, que a sua manutenção é algo absolutamente indesejado; surgem os chamados vícios transrescisórios, que apesar de serem situados no plano da validade não se convalidam, podendo ser alegados a qualquer momento, como ocorre com o vício ou inexistência da citação" (NEVES, 2013, p. 291)
}

No mesmo sentido, THEODORO JR (2009) ensina que sentença em processo com citação nula não pode ser objeto de ação rescisória, diante da inexistência jurídica do processo, não possuindo aptidão para transitar em julgado, motivo pelo qual não há o que rescindir, apenas restando a declaração de nulidade da sentença.

De acordo com Teresa Arruda Alvim (2014, p. 459, apud LEMOS, 2018, p. 902), a sentença deve ser analisada sob três níveis, quais sejam: "a existência jurídica em si mesma, a validade e a eficácia”.

Pontes de Miranda (1998, p. 190-199, apudDIDIER JR, CUNHA, 2017, p. 657-658) já alertava para a diferença entre decisões inexistentes, decisões inválidas (válidas, mas passíveis de ação rescisória) e decisões nulas, que, apesar de serem existentes, podem a qualquer tempo ser objeto de querela nullitatis.

Os pressupostos processuais de existência, segundo MONNERAT (2019), são requisitos lógicojurídicos responsáveis pela existência da relação jurídico-processual, quais sejam, o pedido (que provoca a jurisdição), a jurisdição (função estatal dotada do poder de aplicação do direito) e a citação (ato por meio do qual o réu é integrado à relação jurídico-processual.

3 DIDIER JR e CUNHA (2017) entendem que a medida tem previsão no ordenamento jurídico como hipótese de impugnação ao cumprimento de sentença - arts. 525, I, e 535, I, do CPC, mas que pode assumir feição diversa quando tem por objeto invalidar decisões judiciais inexistentes.

4 Partindo-se da premissa de que houve vício de citação, o réu foi declarado revel e a sentença transitou em julgado em primeiro grau sem interposição de recurso.

$5 \quad$ Em respeito ao postulado da integridade do art. 926 do CPC, havendo acórdão que substituiu a sentença, a querela jamais poderia ser proposta perante o juízo primário, pois um juiz singular não pode desconstituir um acórdão, devendo a querela ser proposta perante a corte prolatora do acórdão. 
Importante esclarecer que o presente estudo não entrará no mérito da discussão acerca da citação ser ou não um pressuposto processual de existência, uma vez que existe divergência doutrinária nesse sentido ${ }^{6}$, de modo que optou-se por conceber a citação como pressuposto processual de existência.

Portanto, ausentes quaisquer dos referidos pressupostos, ainda que a relação jurídico-processual ostente aparência de existência e validade (ex: o processo possui número, fora distribuído e tramita normalmente), este é - e sempre será - considerado juridicamente inexistente, de modo que será, também, inválido, onde eventual sentença proferida nestes autos será igualmente inexistente, porquanto se trata de comando judicial proferido em relação jurídica que não existe no mundo jurídico. "A relação de nulidade sempre será com a validade. Um ato inexistente não é um ato nulo ou anulável, pelo fato de nunca ter existido, não ter validade, o que leva a impossibilidade de anular-se o que não existiu de fato" (LEMOS, 2018, p. 903).

Há divergência acerca da natureza jurídica da ação declaratória de inexistência. LEMOS (2018) entende que a ação tem natureza impugnativa de sentença inexistente, sendo que a sentença proferida na querela nullitatis natureza declaratória, e não constitutiva, porquanto não se pode desconstituir o que sequer existe no mundo jurídico. Partilha do mesmo entendimento Teresa Arruda Alvim (2014, p. 474, apud LEMOS, 2018, P. 904).

Assim, ainda que algumas sentenças, embora inexistentes, mesmo inválidas e ineficazes, produzam efeitos (ex: sentença proferida por um juiz aposentado que é executada e adimplida pelo devedor), tais atos judiciais dependem sempre da declaração judicial de sua inexistência para que haja cessação de seus efeitos e seu reconhecimento como ato judicial inexistente.

Em sentido diverso, entendem pela natureza constitutiva da sentença proferida na querela nullitatis DIDIER JR e CUNHA (2017), os quais discordam da natureza declaratória do pronunciamento judicial, sendo constitutiva a sentença que reconhece o vício transrescisório.

Nessa linha de entendimento, o processo e a decisão judicial seriam existentes, porém, com sua validade fulminada de vícios passíveis de nulidade, de modo que a ação declaratória de inexistência receberia o nome de ação de nulidade de sentença, que, por meio de sentença constitutiva, materializa a presença de uma nulidade, tornando-a ineficaz, a exemplo da hipótese onde se alega vício de citação, no aspecto da validade, alegação que pode ser feita em prazo além do decadencial da ação rescisória, porque se trata de violação ao contraditório.

Ainda sobre vícios transrescisórios, TESHEINER e THAMAY (2016) explicam que se trata de um diminuto rol de vícios que não ensejam a rescisão, mas sim a declaração de inexistência de sentenças que não possuem sequer aptidão para transitar em julgado justamente por não existirem, bem como de sentenças cuja eficácia não tem o condão de atingir determinado lugar, pessoa ou não se opera em circunstâncias específicas ${ }^{7}$.

Dessa forma, o vício transrescisório é aquele de independe de ação rescisória e de gravidade tão extrema que nem mesmo o decurso do tempo é capaz de convalidar ou impedir sua anulação.

Assim, um ato inexistente jamais poderá ser nulo (justamente porque não existe). Por seu turno, um ato judicial existente, porém inválido, deve ser impugnado no curso do processo por meios próprios. Caso não o seja, após o trânsito em julgado, deixa de ser nulidade para se tornar causa de rescindibilidade da sentença, sendo cabível a ação rescisória (caso se enquadre no rol do art. 966).

$6 \quad$ Leonardo Carneiro da Cunha e Fredie Didier (2017) entendem que a citação não é pressuposto processual de existência.

7 Sentença proferida por quem não detém jurisdição (leia-se: não é juiz); ação proposta por quem não pode ser parte ou parte representada por advogado sem procuração, sendo inexistente a petição inicial nesses casos, mas que, por haver condenação em custas e honorários em razão da sentença extintiva do feito, são verdadeiras hipóteses de ineficácia da sentença, que pode ser alegada a qualquer momento, independente de já extrapolado o prazo da ação rescisória; sentença não escrita ou sem a parte dispositiva; sentença nula por impossibilidade de objeto; sentença ineficaz proferida contra quem sequer podia ser parte ou em face de quem fora invalidamente citado (TESHEINER, THAMAY, 2016). 
Todavia, o vício de citação - réu ou litisconsorte passivo necessário unitário não citado, réu citado invalidamente e ocorrência da revelia -, é nulidade tão grave que, justamente por ser nulidade absoluta, não se convalida com o trânsito em julgado ou pelo transcurso do tempo, de modo que a sentença existe, mas será nula, não rescindível.

\section{Conclusão}

Conforme abordado no presente estudo, a querela nullitatis, muito embora tenha sofrido significativa redução de suas hipóteses de cabimento e não possua previsão legal expressa no ordenamento jurídico brasileiro, inobstante muitos juristas entendam que esse instituto já havia desaparecido do direito brasileiro, verificou-se que o mesmo subsiste no direito pátrio, lastreado pela doutrina e pela jurisprudência, e possui inegável importância prática.

Dessa forma, é fundamental identificar o vício do ato judicial para, assim, fazer uso do meio de impugnação adequado para o desfazimento do ato, uma vez que, conforme narrado anteriormente, as consequências jurídicas de um ato judicial inexistente e de um ato nulo são totalmente diferentes, bem assim suas consequências jurídicas e os seus meios impugnativos, até porque, se um ato não existe, jamais poderá ser válido ou mesmo eficaz (pode até ser eficaz no aspecto fático, mas jamais juridicamente). Aliás, nem mesmo nulo um ato inexistente pode ser, pois as nulidades atacam o ato no aspecto da validade.

Nesse sentido, considerando que somente decisões existentes juridicamente podem ser fulminadas de nulidade, a ação rescisória surge como meio adequado para o desfazimento de nulidades constantes no rol do art. 966, onde, passado o prazo decadencial de dois anos, a nulidade do ato é sanada e convalidada, tornando-se coisa julgada soberana e não mais podendo ser atacada por qualquer meio.

Todavia, no caso de atos judiciais inexistentes, seja porque ausentes os pressupostos processuais de existência da relação jurídico-processual, seja porque, muito embora o processo seja plenamente existente e válido, a sentença carece de elementos que a tornem existente (ex: sentença sem assinatura, sem dispositivo, sem fundamento ou proferida por um não-juiz), tais vícios não se convalidam pelo decurso do tempo, tampouco são passíveis de se tornarem coisa julgada soberana, não havendo qualquer limite temporal para o seu desfazimento, o que evidencia a inegável importância prática da querela nullitatis, que ainda subsiste no ordenamento jurídico brasileiro, mas com hipóteses de cabimento muito restritas e que foram sendo cada vez mais reduzidas com o avançar das reformas nos diplomas processuais das últimas décadas.

\section{Referências}

CUNHA, Leonardo Carneiro da. Discursos e Pareceres. $1^{\underline{a}}$ Ed. São Paulo: Salvador, Juspodivm, 2019.

DIDIER JR, Fredie. CUNHA, Leonardo Carneiro da. Curso de Direito Processual Civil - Vol. 03 - Meios de Impugnação às decisões judiciais e Processo nos Tribunais. 14a Ed. Salvador: Juspodivm, 2017.

GAJARDONI, Fernando da Fonseca. Sentenças inexistentes e “querela nullitatis”. Disponível em: $<$ https://edisciplinas.usp.br/mod/folder/view.php?id=174932>. Acesso em 30.06.2020.

LEMOS, Vinícius Silva. Recursos e Processos nos Tribunais no Novo CPC. $2^{\mathrm{a}}$ Ed. ver., ampl. São Paulo: Lexia, 2016.

. Recursos e Processos nos Tribunais. 3 $3^{\underline{a}}$ Ed. Salvador: Juspodivm, 2018.

MONNERAT, Fábio Victor da Fonte. Introdução ao Estudo do Direito Processual Civil. 4ª Ed. São

Paulo: Saraiva Educação, 2019. 
NEVES, Daniel Amorim Assumpção. Manual de Direito Processual Civil - Vol. Único. $5^{\mathrm{a}}$ Ed. rev., atual., ampl. Rio de Janeiro: Forense; São Paulo: Método, 2013.

PASSOS, José Joaquim Calmon de. Esboço de uma Teoria das Nulidades. Revista de Processo - Vol. 56/1989, p. 07-20 / out-dez/1989 - DTR/1989/137.

PORTO, Sérgio Gilberto Porto; USTARRÓZ, Daniel. Lições de Direitos Fundamentais no Processo Civil - O conteúdo processual da Constituição Federal. 1ª Ed. Porto Alegre: Livraria do Advogado, 2009.

TESHEINER, José Maria Rosa; THAMAY, Rennan Faria Krüger. Teoria Geral do Processo - em conformidade com o Novo CPC. $2^{a}$ Ed. Rio de Janeiro: Forense, 2016.

THEODORO JR, Humberto. Código de Processo Civil Anotado. 13aㅡ Ed. rev., ampl., atual. Rio de Janeiro: Forense, 2009. 